\title{
ANALISIS LAJU REAKSI NEUTRON DALAM SEL BAHAN BAKAR NUKLIR PADA REAKTOR CEPAT
}

\author{
Reni Martha, Mohamad Ali Shafii, Afdal \\ Jurusan Fisik a FMIPA Universitas Andalas \\ Kampus Limau Manis, Padang 25136 Po Box 143 \\ Email: Renimartha26@gmail.com
}

\begin{abstract}
ABSTRAK
Analisis laju reaksi neutron dalam sel bahan bakar nuklir pada reaktor cepat sangat penting dilakukan, karena laju reaksi fisi, serapan dan total yang merata dapat mengurangi pemuncakan daya (power peaking) yang tidak diinginkan. Penelitian ini menggunakan metode collision probability $(C P)$ dengan pendekatan flat flux yang melibatkan proses homogenisasi sel bahan bakar nuklir. Dari hasil homogenisasi sel dapat diperoleh distribusi fluks neutron sebagai fungsi energi grup. Selanjutnya dihitung laju reaksi fisi, serapan dan total pada setiap region sel. Laju reaksi fisi mengalami penurunan di daerah energi tinggi akibat adanya peristiwa tumbukan elastik yang menyebabkan neutron lebih mudah kehilangan energy. Laju reaksi serapan berfluktuasi pada bahan bakar, sedangkan pada kelongsong dan pendingin nilainya sangat rendah yaitu kurang dari $5.10^{-4}$ reaksi $/ \mathrm{cm}^{3}$ s. Laju reaksi total mempunyai nilai yang tinggi pada daerah energi tinggi yaitu rentang antara $5 \cdot 10^{-3}$ sampai dengan $2 \cdot 10^{-2}$ reaksi $/ \mathrm{cm}^{3} \mathrm{~s}$ sedangkan pada daerah energi rendah nilainya sangat kecil yaitu kurang dari $5 \cdot 10^{-3}$ reaksi $/ \mathrm{cm}^{3} \mathrm{~s}$.
\end{abstract}

Kata kunci : fluks neutron, laju reaksi, reaktor cepat

\begin{abstract}
Analysis of the neutron reaction rate in the nuclear fuel cells of fast reactor is very important becau se equitable fission, absorption and total reaction rate can reduce the undesirable reactor power pea king. This study uses the collision probability (CP) method with a flat flux approach involving cell homogenization process of nuclear fuel. Neutron flux distribution as a function of group energy ca $\mathrm{n}$ be obtained from the cell homogenization. The reaction rate of fission, absorption and the total in each cell region is calculated. Fission reaction rate decreased in the high energy region due to the events of elastic collision that caused the neutron easier to lose of energy. Reaction rate fluctuates on fuel, whereas on the cladding and the coolant value are very low about $5.10^{-4}$ reaction $/ \mathrm{cm}^{3} \mathrm{~s}$. Total reaction rate has a high value at high energy region that is in the ranges between $5.10^{-3}$ to $2.10^{-2}$ reaction $/ \mathrm{cm}^{3}$ s while at the low energy region is very small value that is less than $5.10^{-3}$ reaction $/ \mathrm{cm}^{3} \mathrm{~s}$.
\end{abstract}

Keywords: neutron flux, the rate of reaction, fast reactor

\section{PENDAHULUAN}

Salah satu bagian yang terpenting dari reaktor adalah teras rektor (Duderstads dan Hamilton, 1976). Teras reaktor terdiri dari dari sejumlah elemen bahan bakar dan elemen non bahan bakar seperti batang kendali, pendingin dan perisai beton. Bahan bakar utama suatu reaktor nuklir cenderung menggunakan bahan fisil yaitu bahan yang mudah berfisi dan mempunyai probabilitas untuk berfisi lebih besar. 
Di dalam reaktor cepat, reaksi fisi harus dikontrol dengan sangat cermat dan teliti, sehingga dalam perancangannya dibutuhkan analisis yang komperehensif. Secara umum analisis tersebut meliputi analisis neutronik, analisis termohidrolik, dan analisis keselamatan. Produksi energi yang terjadi pada sistem reaktor sangat tergantung pada produksi neutron di teras reaktor tersebut. Peluruhan neutron berlangsung secara spontan sehingga pada analisis neutronik pengendalian dari produksi neutron ini sangat menjadi perhatian.

Setelah reaktor beroperasi pada jangka waktu tertentu, maka terjadi penyusutan bahan bakar di setiap lokasi sehingga perlu dilakukan penggantian atau perubahan konfigurasi bahan bakar reaktor. Hal ini dilakukan karena bahan bakar yang terletak pada posisi tengah di dalam teras reaktor mempunyai bagian bakar yang lebih besar daripada bahan bakar yang berada pada posisi pinggir. Oleh karena itu perlu dilakukan perubahan konfigurasi bahan bakar reaktor dengan cara menggeser bahan bakar. Setiap penggantian atau perubahan susunan bahan bakar di dalam teras reaktor akan berpengaruh terhadap distribusi fluks neutron yang dihasilkan pada tiap titik lokasi oleh karena itu perlu dilakukan pengukuran distribusi fluks neutron. Setelah dilakukan pengukuran distribusi fluks neutron, maka dapat dilakukan perhitungan terhadap nilai laju reaksi. Perhitungan laju reaksi juga sangat penting dilakukan seperti perhitungan fluks neutron, karena distribusi fluks dan laju reaksi yang tidak merata dapat mengakibatkan nilai pemuncakan daya (power-peaking) yang tidak diinginkan.

Penelitian yang telah banyak dilakukan hanya sampai perhitungan distribusi fluks neutron. Beberapa diantaranya yaitu perhitungan fluks neutron pada reaktor Kartini dengan dua dimensi dua kelompok (Wulan dan Sumarsono, 1988), dan maksimalisasi fluks neutron cepat pada posisi irradiasi pusat (Central Irradiation Position (CIP )) reaktor G.A. Siwabessy (Riyatun, dkk.,1998).

Penelitian ini bertujuan untuk memperoleh nilai laju reaksi fisi, serapan dan totaldengan pendekatan yang lebih spesifik yang dihitung dalam sebuah sel bahan bakar dalam teras reaktor. Disain reaktor ini menggunakan Uranium-Plutonium Nitrid sebagai bahan bakar dan $\mathrm{Pb}$-Bi sebagai pendingin. Disamping itu, disain reaktor ini juga memerlukan metode komputasi lanjut untuk menjamin akurasi tinggi dalam waktu yang cepat. Data library yang digunakan dalam penelitian ini adalah JFS-3-J33 dari JAEA (Japan Atomic Energy Agency). Pada penelitian ini analisis hanya dilakukan untuk menentukan laju reaksi dalam sel bahan bakar nuklir pada reaktor cepat. Metode yang dipilih dalam penelitian ini adalah metode collision probability (CP) yang didasarkan dari bentuk integral persamaan transport neutron. Simulasi pada penelitian ini menggunakan Borland Delphi 7.0.

\section{TINJAUAN PUSTAKA}

Secara umum persamaan transport neutron dapat dibawa ke dalam bentuk nilai eigen (Shafii, dkk. 2010)

$$
\sum_{j g} V_{j} \varphi_{i g}=\frac{1}{k_{e f f}} \sum_{i} P_{i j g} S_{i g}
$$


dengan $\Sigma_{j g}$ adalah penampang lintang makroskopik, $V_{j}$ adalah volume pada region $\mathrm{j}, \varphi_{i g}$ adalah fluks neutron, $S_{i g}$ merupakan sumber neutron, $k_{\text {eff }}$ adalah faktor multiplikasi efektif dan $P i j$ adalah matriks probabilitas tumbukan yang merupakan fungsi Bickley-Naylor untuk orde tiga (Nakagawa dan Tsucihashi, 1984):

$$
\begin{gathered}
P_{i j}=\frac{2}{\sum_{i} V_{i}} \int_{0}^{r_{i}} d \rho\left[K_{i 3}\left(\lambda_{i j}^{1}\right)-K_{i 3}\left(\lambda_{i j}^{1}+\lambda_{i}\right)-K_{i 3}\left(\lambda_{i j}^{1}+\lambda_{j}\right)+K_{i 3}\left(\lambda_{i j}^{1}+\lambda_{i}+\lambda_{j}\right)\right. \\
\left.K_{i 3}\left(\lambda_{i j}^{2}\right)-K_{i 3}\left(\lambda_{i j}^{2}+\lambda_{i}\right)-K_{i 3}\left(\lambda_{i j}^{2}+\lambda_{j}\right)+K_{i 3}\left(\lambda_{i j}^{2}+\lambda_{i}+\lambda_{j}\right)\right]
\end{gathered}
$$

Dengan mengetahui fluks neutron dan penampang lintang, maka besarnya tingkat interaksi atau laju reaksi dapat ditentukan. Laju reaksi didasarkan pada jumlah interaksi inti neutron.

$$
R R=\varphi_{i g}^{n+1}(N \sigma)=\varphi_{i g}^{n+1} \Sigma_{i j g}
$$

dengan

$R R=$ laju reaksi $\left(\right.$ reaksi $\left./ \mathrm{cm}^{3} \mathrm{~s}\right)$

$\varphi_{i g}^{n+1}=$ fluks neutron $\left(\right.$ reaksi $\left./ \mathrm{cm}^{2} \mathrm{~s}\right)$

$\sigma \quad=$ penampang lintang mikroskopik $\left(\mathrm{cm}^{2}\right)$

$\Sigma_{i j g} \quad=$ penampang lintang makroskopik $\left(\mathrm{cm}^{-1}\right)$

$N=$ rapat jumlah atom $\left(\right.$ atom $\left./ \mathrm{cm}^{2}\right)$

Indeks $i$ menunjukkan region dan $g$ grup energi. Berdasarkan jenis penampang lintang, laju reaksi dapat dibedakan menjadi laju reaksi fisi, laju reaksi serapan dan laju reaksi total. Laju reaksi fisi dapat dinyatakan sebagai,

$$
R R_{f}=\Sigma_{f} \varphi_{i g}^{n+1}
$$

dengan $\Sigma_{f}$ adalah penampang lintang makroskopik fisi, dan $\varphi_{i g}^{n+1}$ adalah fluks neutron.

Laju reaksi serapan dapat ditulis sebagai,

$$
R R_{a}=\Sigma_{a} \varphi_{i g}^{n+1}
$$

dengan $\Sigma_{a}$ adalah penampang lintang makroskopik serapan.

Dan laju reaksi total dapat dihitung dengan,

$$
R R_{t}=\Sigma_{t} \varphi_{i g}^{n+1}
$$

dengan $\Sigma_{t}$ adalah penampang lintang total.

\section{METODE PENELITIAN}

Geometri sel dipilih berbentuk silinder yang dibagi dalam tiga region yaitu: region 1 adalah bahan bakar (fuel) yang terdiri 3 mesh yaitu mesh ke-1, 2, 3, region 2 adalah struktur (cladding) yang terdiri dari 1 mesh yaitu mesh ke-4 dan region 3 adalah pendingin (coolant) yang terdiri dari 2 mesh yaitu mesh ke-5,6 seperti terlihat pada Gambar 1. Bahan bakar yang digunakan dalam penelitian ini adalah campuran U-Pu Nitrid, bahan struktur kelongsongnya adalah stainless steel dan $\mathrm{Pb}-\mathrm{Bi}$ sebagai pendingin. Sedangkan spesifikasi disain sel bahan bakar nuklir terlihat pada Tabel 1 
Penelitian ini dilakukan dengan metode simulasi komputasi menggunakan bahasa pemograman Borland Delphi 7.0. Program yang digunakan adalah program homogenisasi sel. Perhitungan laju reaksi diterapkan pada model sel bahan bakar nuklir berbentuk silinder satu dimensi dengan 70 grup energi. Data library yang digunakan dalam penelitian ini adalah JFS-3-J33 dari JAEA (Japan Atomic Energy Agency). Library ini menyediakan grup konstan bagi komputer SLAROM.

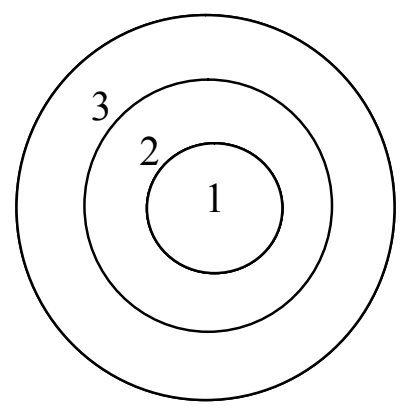

Gambar 1. Pembagian region dalam sel

Tabel 1. Spesifikasi disain sel bahan bakar nuklir (Shafii, dkk., 2012)

\begin{tabular}{|l|c|}
\hline \multicolumn{1}{|c|}{ Parameter } & Spesifikasi \\
\hline Bahan bakar & Uranium-Plutonium Nitrida \\
\hline Bentuk sel & Silinder 1D \\
\hline Struktur material & Stainless steel \\
\hline Pendingin & Timbal-Bismuth $(\mathrm{Pb}-\mathrm{Bi})$ \\
\hline Diameter pin bahan bakar & $1.134 \mathrm{~cm}$ \\
\hline Tebal cladding & $0.11 \mathrm{~cm}$ \\
\hline Temperatur rata-rata & $1383 \mathrm{~K}$ \\
\hline Fraksi volume sel: bahan bakar & $61.73 \%$ \\
Struktur & $19.49 \%$ \\
pendingin & $18.87 \%$ \\
\hline
\end{tabular}

Secara umum langkah kerja pada penelitian ini dimulai dengan langkah-langkah persiapan yaitu menetapkan spesifikasi disain reaktor yang akan disimulasikan pada file data masukan (input). Perhitungan laju reaksi merupakan hasil perkalian fluks neutron dan penampang lintang makroskpik.

Untuk menghitung fluks neutron dan laju reaksi dimulai dengan menentukan nilai awal $k_{\text {eff }}$, dilanjutkan dengan memasukan fluks awal $\chi_{i g}$ untuk seluruh region dan grup yang diperoleh dari data library, kemudian menghitung suku sumber disetiap region dan grup energi. Proses dilanjutkan dengan menghitung fluks neutron di setiap region dan grup energi. Setelah diperoleh nilai fluks neutron, langkah selanjutnya adalah perhitungan laju reaksi yang merupakan hasil perkalian fluks neutron dan penampang lintang makroskopik. Alur perhitungan fluks neutron dan laju reaksi ditunjukkan pada diagram alir pada Gambar 2. 


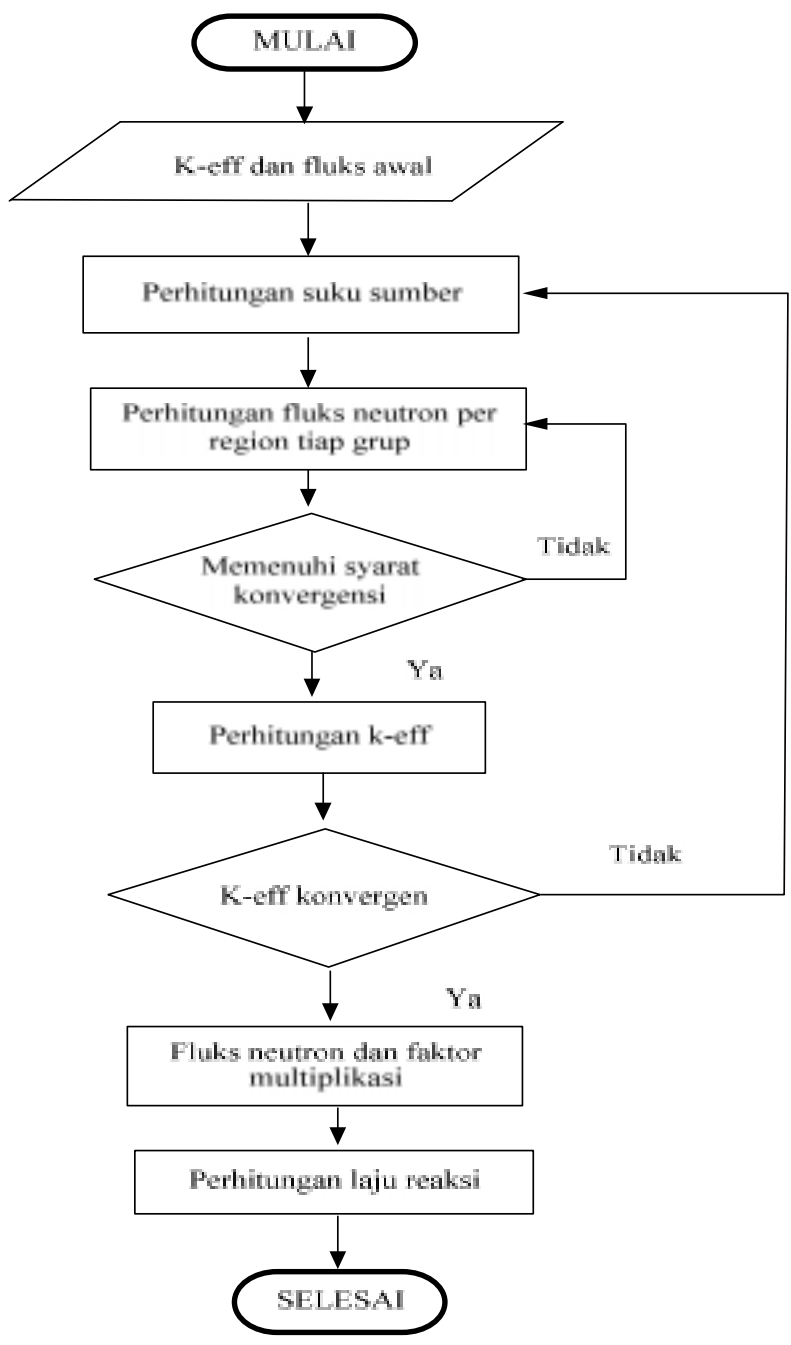

Gambar 2. Alur perhitungan fluks neutron multigrup dan laju reaksi

\section{HASIL DAN DISKUSI}

Dari Gambar 3 terlihat bahwa laju reaksi fisi hanya terjadi pada daerah bahan bakar, sedangkan pada daerah kelongsong dan pendingin tidak terjadi karena pada kedua daerah tersebut tidak terjadi reaksi fisi. Dari gambar juga terlihat bahwa laju reaksi fisi mengalami penurunan di daerah energi tinggi akibat adanya peristiwa tumbukan elastis yang menyebabkan neutron lebih mudah kehilangan energi sehingga laju reaksi fisinya juga mengalami penurunan. Pada energi tengahan (intermediate), laju reaksi mengalami resonansi dan pada daerah ini disebut daerah energi resonan. Pada daerah ini terjadi tumpang tindih (overlap) yang sangat kuat sehingga hanya menghasilkan sedikit perubahan. Untuk semua reaktor, neutron banyak diserap di daerah energi resonan, namun daerah resonan dapat berubah dengan adanya perubahan suhu pada bahan bakar akibat adanya efek pelebaran Doppler (Bell dan Glasstone, 1970) . 


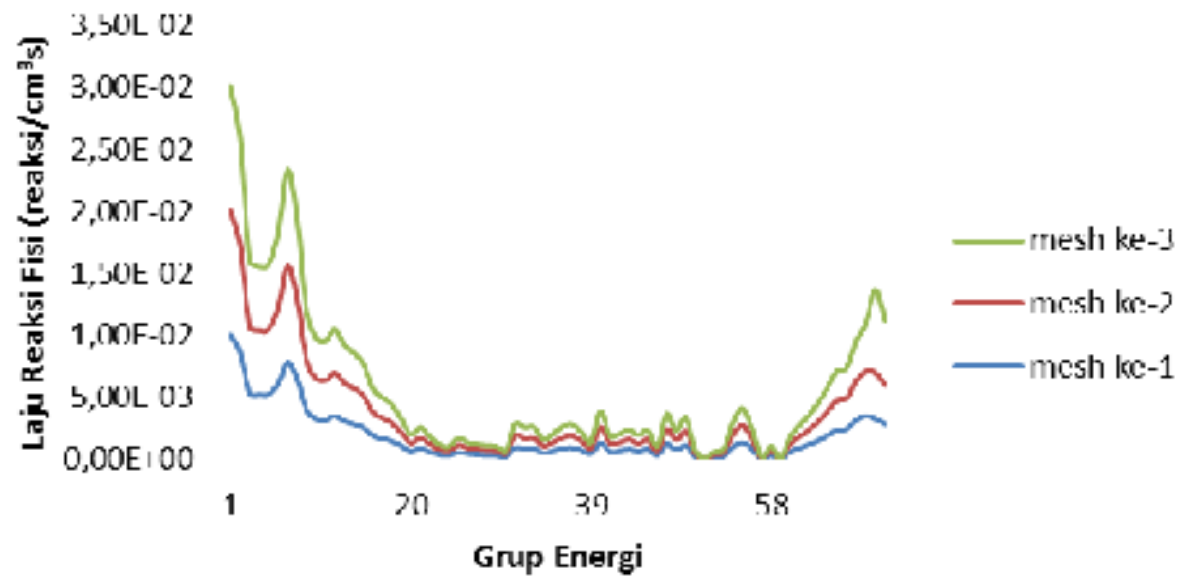

Gambar 3. Laju reaksi fisi dengan 6 mesh

Gambar 4 terlihat bahwa nilai laju reaksi serapan pada bahan bakar baik untuk daerah energi rendah maupun tinggi sangat berfluktuasi. Berfluktuasinya nilai laju serapan akibat terjadinya ketidakstabilan neutron pada daerah resonan. Sedangkan laju reaksi serapan pada kelongsong dan pendingin nilainya sangat rendah, baik untuk daerah energi rendah maupun tinggi karena adanya efek moderasi atau penurunan neutron, dimana dalam proses ini tumbukan elastis menghilangkan fraksi ketergantungan terhadap energi pada setiap tumbukan, sehingga neutron lebih banyak hilang pada kelongsong dan pendingin.

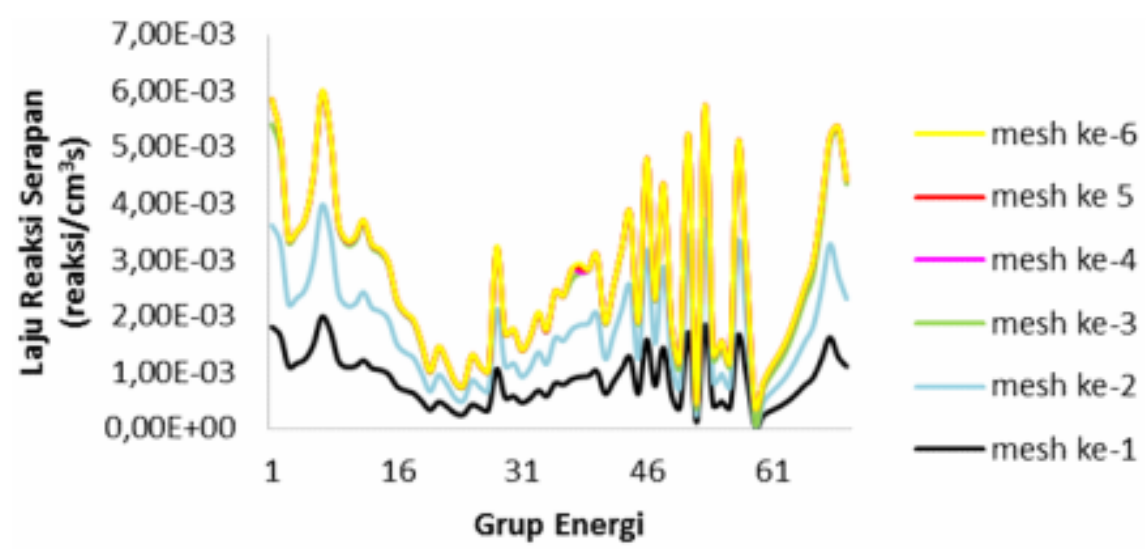

Gambar 4. Laju reaksi serapan dengan 6 mesh

Gambar 5 memperlihatkan laju reaksi total. Dari gambar terlihat bahwa laju reaksi total untuk ketiga daerah yaitu bahan bakar, kelongsong dan pendingin cenderung mengalami penurunan. Sama halnya dengan fluks neutron, laju reaksi total mempunyai nilai tinggi pada daerah energi tinggi. Sedangkan pada daerah energi rendah nilai laju reaksi total sangat kecil. Hal ini terjadi karena jenis reaktor yang digunakan dalam penelitian ini adalah jenis reaktor cepat. 


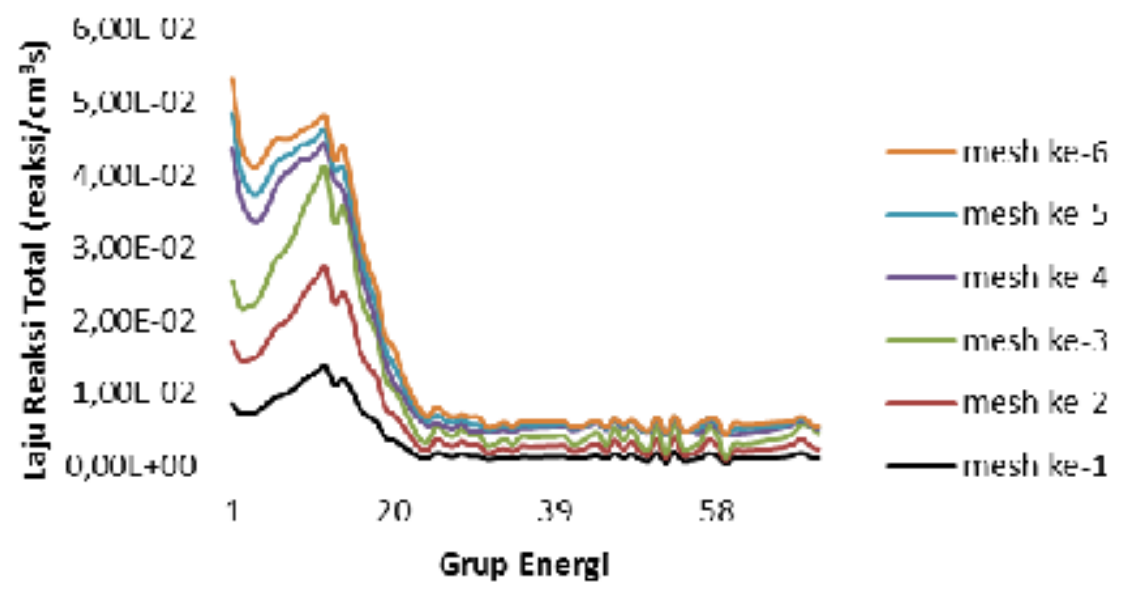

Gambar 5. Laju reaksi total dengan 6 mesh

\section{KESIMPULAN DAN SARAN}

Laju reaksi fisi mengalami penurunan di daerah energi tinggi akibat adanya peristiwa tumbukan elastik yang menyebabkan neutron lebih mudah kehilangan energi, laju reaksi serapan berfluktuasi pada bahan bakar, sedangkan pada kelongsong dan pendingin nilainya sangat rendah yaitu kurang dari $5.10^{-4} \mathrm{reaksi} / \mathrm{cm}^{3} \mathrm{~s}$. Laju reaksi total mempunyai nilai yang tinggi pada daerah energi tinggi yaitu rentang antara $5.10^{-3}$ sampai dengan $2.10^{-2}$ reaksi $/ \mathrm{cm}^{3} \mathrm{~s}$ sedangkan pada daerah energi rendah nilainya sangat kecil yaitu kurang dari $5.10^{-3} \mathrm{reaksi} / \mathrm{cm}^{3} \mathrm{~s}$.

\section{DAFTAR PUSTAKA}

1. Bell, G, dan Glasstone, S. 1970, Nuclear Reactor Theory, Van Nostrand Reinhold Company, New York.

2. Duderstad, JJ., dan Hamilton, L.J., 1976, Nuclear Reactor Analisys, Jhon wiley and Sons, New York.

3. Nakagawa, M., dan Tsuchihashi, K., 1984, SLAROM : A Code For Cell Homogenization Calculation Of Fast Reactor, Department of Reactor Engineering, Tokai Research Institute.

4. Riyatun, Prayoto dan Istianto, J.E., 1998, Maksimalisasi Fluks Neutron Cepat pada Posisi Irradiasi Pusat (CIP) Reaktor G.A. Siwabessy, PPS UGM.

5. Shafii, M.A, dkk, 2010, Neutron Flux Interpolation with Finite Element Method in the Nuclear Fuel Cell Calculation using Collision Probability Method, http://proceedings.aip.org/about/rights_permissions, diakses : mei 2013

6. Shafii, M.A, 2012, Nuclear Fuel Cell Calculation Using Collision Probability Method with Linear Non Flat Flux Approach, World Journal of Nuclear Science and Technology, 2012, 2, 49-53 
7. Wulan, T. dan Soemarsono, B., 1988, Perhitungan Fluks Neutron pada Reaktor Kartini dengan Dua Dimensi Dua Kelompok, Pusat Penelitian Nuklir Yogyakarta. 